\title{
The Effect of Cosmetic Talc Powder on Health
}

\author{
Khaled Ali Al Awam, Saumy Johnson, Afaf Alonazi, Amjad Abo Aleeh, Afnan Aldhamen, Anwar Alhaddad, Salma Alnouf, Faten Almutairi, Rawan Zila, \\ Reema Algoud, Dania Alghurab, Mona Alsayegh, Batool Alnakli \\ Department of Respiratory Therapy Sciences, Inaya Medical College, Riyadh, Saudi Arabia
}

\section{Abstract}

Talc powder is widely used for different purposes worldwide. Effects of talc on the human health is a concern as it has many chemical components. This review is an attempt to present the relevant researches in this field and to summarize the current updates about the topic. Talcum powder exposure has been shown to be a reason in the development of mesotheliomas and carcinoma of the lung in women. Regular cosmetic powders can get attached to larger particles that would deposit in the upper airways of the human respiratory system. The alveolar region is the second most exposed region of the respiratory system. Deposition levels in the tracheobronchial region is the lowest. Cosmetic talc powder, used regularly by women worldwide, can cause detrimental effects on different organ systems of the human body. Awareness on its harmful effects to the users may be useful to reduce the usage to some extent.

Keywords: Pleurodesis, pulmonary diseases, talc powder

\section{INTRODUCTION}

Talc belongs to the general mineral family of the layered silicates which are present in nature and are composed of crystalline hydrous magnesium silicate. In combination with magnesite, it is available worldwide. It is also possible to find pure talc. Commercial use is possible after sorting where talc crystals are milled or micronized to fine powders. Talc structure is soft and chemically inactive with bright white color in general. Its color may be changed by staining with iron or impurity by other minerals. It is not specifically deemed dangerous and is classified as an irritant dust in powder form. ${ }^{[1]}$

Two types of talc, industrial and cosmetic, are used in paper, plastics, rubber, paint, and cosmetic manufacturing work. ${ }^{[2,3]}$ Furthermore, these substances have been shown to be effective for use through tube thoracostomy. These include cosmetic talc and iodopovidone. These are considered to be safe ${ }^{[4]}$ Cosmetic powder is packaged as a compact powder or a loose powder, which is used for makeup, and contains heavy metals such as $\mathrm{Cd}$, $\mathrm{Co}, \mathrm{Pb}, \mathrm{Cu}$, and $\mathrm{Cr}$. A study on thirty different brands of talcum powder showed that metals are present in safe limits, but the excess use of talcum powder affects the health of the consumer. ${ }^{[5]}$ Some studies have shown that exposure to cosmetic talc grades is considered to be much lower than in talc mills and mines. ${ }^{[3]}$ Preservatives and fragrances are added to cosmetic products

\begin{tabular}{|l|l|}
\hline \multicolumn{2}{|c|}{ Access this article online } \\
\hline Quick Response Code: & Website: \\
\hline & www.ijrconline.org \\
\cline { 2 - 2 } & \\
\hline
\end{tabular}

to add an attractive aroma and presentation to the customers. Cosmetic powders are of poor antimicrobiological quality. They may be the sources for microorganisms to grow and are more contaminated with fungi than with bacteria. Some chemical compounds are added to avoid the microbial growth. However, microorganisms may cause damage or chemical changes in cosmetic products. ${ }^{[-8-8]} \mathrm{A}$ few of the components in the cosmetics can enter the skin and might cause systemic effects. ${ }^{[9]}$

In 2005, a study was done on several facial cosmetics available in Nigeria and it showed that the regular use of cosmetics might end up in escalation in the quantity of trace metal in the human body beyond the safety range, especially in ocular system. ${ }^{[10,11]}$ In 2012, the first case of severe endobronchitis using talcum powder was reported in a female patient. ${ }^{[12]}$

A study on rats was done by Shim et al. on talc involving both male and female Sprague-Dawley rats with recurrent 4 weeks of toxicity through the inhalational route to the whole body. Rats were given the trial of talc (inhaled) in different concentrations such as $0,5,50$, and $100 \mathrm{mg} / \mathrm{m}^{3}$ for

Address for correspondence: Dr. Khaled Ali Al Awam, Respiratory Therapy Program, Inaya Medical College, P. O. Box: 271880 Riyadh 11352, Saudi Arabia. E-mail: kalawam@inaya.edu.sa

This is an open access journal, and articles are distributed under the terms of the Creative Commons Attribution-NonCommercial-ShareAlike 4.0 License, which allows others to remix, tweak, and build upon the work non-commercially, as long as appropriate credit is given and the new creations are licensed under the identical terms.

For reprints contact: reprints@medknow.com

How to cite this article: Al Awam KA, Johnson S, Alonazi A, Aleeh AA, Aldhamen A, Alhaddad A, et al. The effect of cosmetic talc powder on health. Indian J Respir Care 2019;8:18-21. 
$6 \mathrm{~h} /$ day, for 5 days a week, for 4 weeks. The study reported no adverse events or death of the rats that were exposed to talc. A reduction in glucose was seen in male rats exposed to 50 and $100 \mathrm{mg} / \mathrm{m}^{3}$ of talc. Furthermore, insinuation of macrophages both in the walls of the alveoli and spaces adjacent to the terminal and respiratory bronchioles was observed during histopathological analysis. Superoxide dismutase 2, a classic genetic sign of oxidative damage, was present in both male and female rats exposed to $100 \mathrm{mg} / \mathrm{m}^{3}$ talc. They concluded that macrophage aggregations were prompted by the inhalation of talc. In fact, damage to the lung could be attributed to the oxidative stress. ${ }^{[13]}$

\section{Talc and Pulmonary Diseases}

Talc causes four types of pulmonary diseases; three associated with aspiration (talcosilicosis, talcoasbestosis, and talcosis) and one by intravenous administration of talc. The latter is seen in drug abusers who inject medications intended for oral use. Indicatives of pulmonary talcosis seen by high-resolution computed tomography (CT) showed small centrilobular nodules associated with heterogeneous conglomerate masses. These consist of high-density amorphous areas, with or without panlobular emphysema in the lower lobes. Histopathologic studies in a case report showed the presence of birefringent, needle-shaped particles of talc inside the giant cells with areas of pulmonary fibrosis associated with the use of polarized light in talc pneumoconiosis. The authors concluded that CT plays a vital role in the diagnosis of pulmonary talcosis, as indicative configurations may be seen ${ }^{[14]}$ If this kind of pattern is seen in patients with a history of contact with talc or in drug abuser, it is greatly indicative of pulmonary talcosis as shown in Figure $1 \mathrm{a}$ and $\mathrm{b} \cdot{ }^{[2]}$

\section{Pathophysiology}

The pathophysiology of talcosis may be similar to that of sarcoidosis. Talc granulomatosis is classically associated with high concentrations of serum anticholinesterase and a large number of lymphocytes in bronchoalveolar lavage. A person who has sarcoidosis must go through a comprehensive interview about exposure to organic or inorganic dusts. Corticosteroids in the treatment modality reduce symptoms

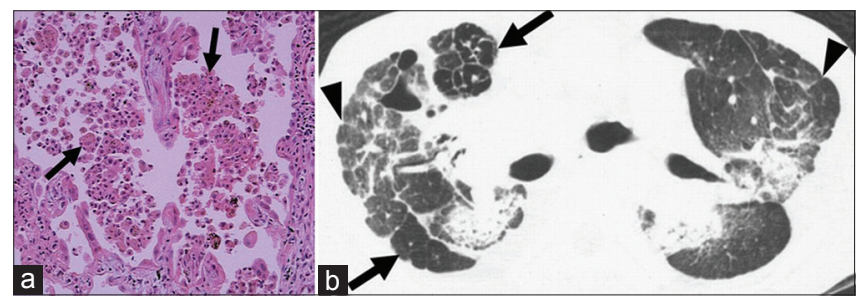

Figure 1: ( $a$ and $b$ ) Dense consolidation at the level of the main bronchi, with dilated bronchi, pericicatricial emphysematous changes (arrows), ground-glass opacities, and interlobular septal thickening (arrowheads) in the upper lobe of both lungs seen by axial thin section computed tomography scan (1.5-mm-thick section) in a patient who worked for 8 years in the processing of magnesium silicate and improve pulmonary function, though the possibility of relapse exists after the completion of treatment.

Substantial similarity in signs and symptoms and imaging and laboratory parameters among patients presenting with pulmonary fibrosis requires a detailed interview and will be the key to identification of the disease.

Shinno et al. presented a case series of acute respiratory distress syndrome (ARDS) subsequent to pleurodesis with macroparticle size talc (2018). They found out that advance in the age and presence of any interstitial changes in the lung as shown in $\mathrm{CT}$ of the chest are the likely risk elements for the presence of posttalc pleurodesis-ARDS. ${ }^{[15,16]}$ Some studies showed successful talc pleurodesis outcomes in patients with abundant malignant pleural effusion by using pleurodesis with thoracoscopic talc insufflations or with talc slurry instillation with similar success rate. ${ }^{[17]}$ Success depends on several factors including female gender, Karnofsky Performance Score $>70$, pleural fluid $\mathrm{pH} \geq 7.34$, adenosine deaminase $\geq 18 \mathrm{IU} / 1$, and pleural fluid cholesterol $\leq 82 \mathrm{mg} / \mathrm{dl} .{ }^{[18,19]}$

A study done in Germany showed a positive association between asbestos, talc, carcinoma of the lung, laryngeal carcinoma, and carcinoma of the stomach among rubber workers. Deaths from noncarcinomatous pulmonary diseases also increased when exposed to talc. ${ }^{[17,18]}$ Long-term exposure to talc powder may cause chronic bronchitis and pneumocystis. ${ }^{[20-22]}$

Talcum powder exposure has been shown to be a reason in the development of mesotheliomas and carcinoma of the lung in women. ${ }^{[23,24]}$ Exposure to talc free of silica and asbestos causes both pneumoconiosis and chronic respiratory impairment. There are many researches on the effects of talc on different organ systems [Table 1]. Miners and millers exposed to talc free of asbestos and silica developed obstructive pulmonary effects. ${ }^{[25]}$

\section{Safer Use OF Talc}

Talc is used in the treatment of idiopathic spontaneous pneumothorax although it might result in a mild restrictive

\begin{tabular}{|c|c|}
\hline Researches & Effect of talc on health \\
\hline Frank $C^{[15]}$ & Pulmonary talcosis \\
\hline Shinno et al. ${ }^{[16]}$ & ARDS, ALI \\
\hline Yildirim et al..$^{[19]}$ & Chronic bronchitis \\
\hline Straif et al..$^{[20]}$ & Pneumocystis, pneumoconiosis \\
\hline Wild et al..$^{[21]}$ & Lung cancer and laryngeal cancer \\
\hline \multicolumn{2}{|l|}{ Hildick-Smith $^{[32]}$} \\
\hline Wegman et al..$^{[25]}$ & Ovarian cancer \\
\hline Karageorgi et al. ${ }^{[33]}$ & Endometrial cancer risk \\
\hline Kuzniar et al. ${ }^{[31]}$ & Severe hypoxemia \\
\hline Genofre et al. ${ }^{[8]}$ & Inflammatory response \\
\hline Lange et al..$^{[24]}$ & Impairment of lung function and pleural thickening \\
\hline
\end{tabular}

ARDS: Acute respiratory distress syndrome, ALI: Acute lung injury 
impairment of lung function and pleural thickening as seen in the chest X-ray. ${ }^{[24]}$

There are articles in the literature which conclude that talc is not harmful. Genes GSTM1 and GSTT1 in women can be varied and this variation is found to affect the association of the use of genital talc and the risk of ovarian cancer. ${ }^{[26]}$ An analysis of authentic historical Italian cosmetic talc sample by Ilgren et al. through selected area electron diffraction combined with energy dispersive X-ray analysis found that Pinerolo Italian cosmetic talc does not cause any cancer risk, which is due to its purity. ${ }^{[27,28]}$ Similarly, French and Austrian talc workers were examined for the effects of talc dust on respiratory system using pulmonary function test and chest X-ray, but neither showed any evidence of detrimental effects of talc exposure. ${ }^{[29]}$

Regular cosmetic powders can get attached to larger particles that would deposit in the upper airways of the human respiratory system. The alveolar region was the second most exposed region of the respiratory system. Deposition levels in the tracheobronchial region were the lowest. Both routinely mixed and small talc particles result in an inflammatory response. Both types of particles were seen to be deposited in the lungs, spleen, liver, and kidneys of animal studies. ${ }^{[30]}$ The medical thoracoscopic talc pleurodesis is an analgesic and useful remedy for malignant pleural effusion. ${ }^{[31]}$ Use of talc powder in the perineal area is shown to increase the chance of endometrial cancer. This is more prevalent among postmenopausal women. ${ }^{[33]}$

\section{Conclusion}

Cosmetic talc powder, used regularly by women worldwide, can cause detrimental effects on different organ systems of the human body. Awareness on its harmful effects to the users may be useful to reduce the usage to some extent. Further research is needed to obtain more evidence regarding its effects on the pulmonary system.

\section{Financial support and sponsorship}

Nil.

\section{Conflicts of interest}

There are no conflicts of interest.

\section{References}

1. McCarthy E. Talc. Kirk-Othmer Encyclopedia of Chemical Technology; 2000. Available from: https://www.doi.org/10.1002/0471238961.20011 20313030301.a01. [Last accessed on 2000 Dec 04].

2. Marchiori E, Lourenço S, Gasparetto TD, Zanetti G, Mano CM, Nobre LF, et al. Pulmonary talcosis: Imaging findings. Lung 2010;188:165-71.

3. Choosong T, Phakthongsuk P. Health status of workers exposed to talcum powder in hospitals in Southern Thailand. Aerosol Air Qual Res 2006;6:397-405.

4. Agarwal R, Paul AS, Aggarwal AN, Gupta D, Jindal SK. A randomized controlled trial of the efficacy of cosmetic talc compared with iodopovidone for chemical pleurodesis. Respirology 2011;16:1064-9.

5. Rehman G, Bukhari IH, Riaz M, Manzoor HS, Rasool N, Khalid A, et al. Determination of toxic heavy metals in different brands of talcum powder. Int J Appl Nat Sci 2013;2:45-52.

6. Chen J, Li Z, Xu N, Zhang X, Wang Y, Lin D, et al. Efficacy of medical thoracoscopic talc pleurodesis in malignant pleural effusion caused by different types of tumors and different pathological classifications of lung cancer. Int J Clin Exp Med 2015;8:18945-53.

7. SI SN, Praveena SM. Hazardous ingredients in cosmetics and personal care products and health concern: A review. Public Health Res 2015;5:7-15.

8. Genofre EH, Vargas FS, Acencio MM, Antonangelo L, Teixeira LR, Marchi E, et al. Talc pleurodesis: Evidence of systemic inflammatory response to small size talc particles. Respir Med 2009;103:91-7.

9. Dashen MM, Chollom PF, Okechalu JN, Ma'aji JA. Microbiological quality assessment of some brands of cosmetics powders sold within Jos metropolis, plateau state. J Microbiol Biotechnol Res 2017;1:101-6.

10. Nouioui MA, Mahjoubi S, Ghorbel A, Ben Haj Yahia M, Amira D, Ghorbel $\mathrm{H}$, et al. Health risk assessment of heavy metals in traditional cosmetics sold in Tunisian local markets. Int Sch Res Notices 2016;2016:6296458.

11. Nnorom IC, Igwe JC, Oji-Nnorom CG. Trace metal contents of facial (make-up) cosmetics commonly used in Nigeria. Afr J Biotechnol 2005;4:1133-8.

12. Ong TH, Takano A. Severe endobronchitis and airway stricture caused by inhalation of cosmetic talc. Chest 2012;142:511-3.

13. Shim I, Kim HM, Yang S, Choi M, Seo GB, Lee BW, et al. Inhalation of talc induces infiltration of macrophages and up regulation of manganese superoxide dismutase in rats. Int J Toxicol 2015;34:491-9.

14. Chong S, Lee KS, Chung MJ, Han J, Kwon OJ, Kim TS, et al. Pneumoconiosis: Comparison of imaging and pathologic findings. Radiographics 2006;26:59-77.

15. Frank C, Jorge L. An uncommon hazard: Pulmonary talcosis as a result of recurrent aspiration of baby powder. Respir Med 2011;4:109-11.

16. Shinno Y, Kage H, Chino H, Inaba A, Arakawa S, Noguchi S, et al. Old age and underlying interstitial abnormalities are risk factors for development of ARDS after pleurodesis using limited amount of large particle size talc. Respirology 2018;23:55-9.

17. Rehse DH, Aye RW, Florence MG. Respiratory failure following talc pleurodesis. Am J Surg 1999;177:437-40.

18. Debeljak A, Kecelj P, Triller N, Letonja S, Kern I, Debevec L, et al. Talc pleurodesis: Comparison of talc slurry instillation with thoracoscopic talc insufflation for malignant pleural effusions. J BUON 2006;11:463-7.

19. Yildirim H, Metintas M, Ak G, Metintas S, Erginel S. Predictors of talc pleurodesis outcome in patients with malignant pleural effusions. Lung Cancer 2008;62:139-44.

20. Straif K, Keil U, Taeger D, Holthenrich D, Sun Y, Bungers M, et al. Exposure to nitrosamines, carbon black, asbestos, and talc and mortality from stomach, lung, and laryngeal cancer in a cohort of rubber workers. Am J Epidemiol 2000;152:297-306.

21. Wild P, Leodolter K, Réfrégier M, Schmidt H, Zidek T, Haidinger G, et al. A cohort mortality and nested case-control study of French and Austrian talc workers. Occup Environ Med 2002;59:98-105.

22. Wild P, Réfrégier M, Auburtin G, Carton B, Moulin JJ. Survey of the respiratory health of the workers of a talc producing factory. Occup Environ Med 1995;52:470-7.

23. Gordon RE, Fitzgerald S, Millette J. Asbestos in commercial cosmetic talcum powder as a cause of mesothelioma in women. Int $\mathrm{J}$ Occup Environ Health 2014;20:318-32.

24. Lange P, Mortensen J, Groth S. Lung function 22-35 years after treatment of idiopathic spontaneous pneumothorax with talc poudrage or simple drainage. Thorax 1988;43:559-61.

25. Wegman DH, Peters JM, Boundy MG, Smith TJ. Evaluation of respiratory effects in miners and millers exposed to talc free of asbestos and silica. Br J Ind Med 1982;39:233-8.

26. Gates MA, Tworoger SS, Terry KL, Titus-Ernstoff L, Rosner B, De Vivo I, et al. Talc use, variants of the GSTM1, GSTT1, and NAT2 genes, and risk of epithelial ovarian cancer. Cancer Epidemiol Biomarkers Prev 2008; 17:2436-44.

27. Ilgren EB, Sartorio C, Hoskins J. Analysis of an authentic historical Italian cosmetic talc sample-further evidence for the lack of cancer risk. Environ Pollut 2017;6:6. 
Al Awam, et al.: Effect of cosmetic talc powder

28. Anderson EL, Sheehan PJ, Kalmes RM, Griffin JR. Assessment of health risk from historical use of cosmetic talcum powder. Risk Anal 2017;37:918-29.

29. Wild P, Leodolter K, Réfrégier M, Schmidt H, Bourgkard E. Effects of talc dust on respiratory health: Results of a longitudinal survey of 378 French and Austrian talc workers. Occup Environ Med 2008;65:261-7.

30. Nazarenko Y, Zhen H, Han T, Lioy PJ, Mainelis G. Potential for inhalation exposure to engineered nanoparticles from nanotechnology-based cosmetic powders. Environ Health Perspect 2012;120:885-92.

31. Kuzniar TJ, Blum MG, Kasibowska-Kuzniar K, Mutlu GM. Predictors of acute lung injury and severe hypoxemia in patients undergoing operative talc pleurodesis. Ann Thorac Surg 2006;82:1976-81.

32. Hildick-Smith GY. The biology of talc. Occup Environ Med 1976;33:217-29.

33. Karageorgi S, Gates MA, Hankinson SE, De Vivo I. Perineal use of talcum powder and endometrial cancer risk. Cancer Epidemiol Biomarkers Prev 2010;19:1269-75. 